\title{
大都市における既設道路橋の地震防災上の 重要度の評価手法
}

\author{
佐藤次郎 ${ }^{1} \cdot$ 篠崎之雄 $^{2} \cdot$ 佐伯光昭 ${ }^{3} \cdot$ 磯山龍二 $^{4}$ \\ 1 正会員 東京都建設局参事（東京都道路公社建設部長）（１63-01 東京都新宿区西新宿 2-8-1） \\ ${ }^{2}$ 正会員 東京都建設局 第五建設事務所工事課 係長 \\ ${ }^{3}$ 正会員 工博 日本技術開発（株）地震防災部部長 \\ ${ }^{4}$ 正会員 工博 日本技術開発（株）地震防災部次長
}

\begin{abstract}
大都市の地域防災計画を策定する上で道路網の震後機能を維持することは, 最も重要な課題である. 中でも, 道路橋は一旦被害を受けた場合の影響が大きく, その耐震性の確保は極めて重要である. 一方, 地震防災対策計 画を合理的に策定するためには, 対策の優先順位を定める必要がある. 本研究は, 既設橋の地震防災対策事業実 施の優先順位を合理的に設定するため, 橋の地震防災上の重要度の評価手法を実務的な観点から提案するもので ある. 道路の路線・ 区間としての重要度と橋の被災時の影響度の 2 種類の因子の組み合わせにより, 橋の防災上 の重要度を新たに定義・分類した.この提案した手法を東京都の道路網に適用し, 実用性のあることを示した.
\end{abstract}

Key Words : criticality, priority, retroffiting, emergency response, road network, Tokyo Metropolitan Area

1. まえがき

わが国の大都市は臨海部の沖積低地に位置し, 比較的 川幅の広い河口部に発展したところが多い.このため, 大都市には多くの橋が存在し, それらは過酷な使用環境 のもとで本来果たすべき交通機能に加えてライフライン の占用空間として社会・経済活動にきわめて重要な役割 を果たしている.そして,これらの橋は時代の変遷に伴っ て順次建設され，様々な年代の整備水準の異なるものが 混在している状況にある. 東京都を例にとればその建設 時期は, 関東大地震後の復興期, 第二次大戦後の復興期, 高度経済成長期の 3 つに大別される.

このような橋の重要性を踏まえて，過去数回にわたつ て全国的な道路橋の震災点検 ${ }^{11}$ が実施されてきた.この 結果等に基づき, 国や地方自治体では防災業務計画や地 域防災計画の中で橋の対策計画を位置付け，基本的には 耐震性の低い橋に対して落橋等の致命的な崩壊の危険性 への対応を主とした対策を施すという考え方に基づい て, 落橋防止装置の設置や液状化対策などが施されてき た.

しかしながら, 複雑かつ広範な街路網に多種多様な橋 をかかえる大都市では, 地震により橋が被害を受けた場 合の地域社会, 地域経済に与える影響が大きいことから, このような橋のみを単独にみて, かつ画一的な整備水準 を求める計画論の適用はなじまない. 災害時の都市を構
成する街路網の使われ方に主眼をおいて, 道路の線, 街 路を構成する面としての特性を考慮した街路網における 個々の橋の重要度を評価し，これに基づく優先順位を付 し, 計画的かつ段階的に対応していくことがより合理的 である。

供用中の橋の耐震補強計画における重要度の概念はア メリカ合衆国に見られる21-4).これらは基本的に州内や 州間を結ぶ高速道路の橋に対して提案されたもので Buckle ${ }^{4)}$ に代表される考え方は，あくまで単一のある いはマクロな高速道路網に対して適用されるものであ り, わが国の大都市の街路の橋にそのまま用いるのは適 切ではない. 先に述べたわが国の大都市の橋の特性に根 ざした新たな重要度の評価方法を導入する必要がある.

本研究ではこのような観点から, 大都市における供用 中の多数の橋の震前ならびに震後対策事業の対象亡なる 橋の抽出と優先順位の設定に反映させるため, 上述した 重要度を新たに「橋の地震防災上の重要度」として定義 し, その評価手法を実務的な観点から提案したものであ る.さらに，この手法を東京都建設局管理の橋に適用し その実用性を検証した。

\section{2. 橋の耐震対策計画の考え方と重要度の意味}

耐震対策計画を立案するためには，橋の重要度と耐震 性の 2 つの要素を考慮する必要がある. 一般には両者を 


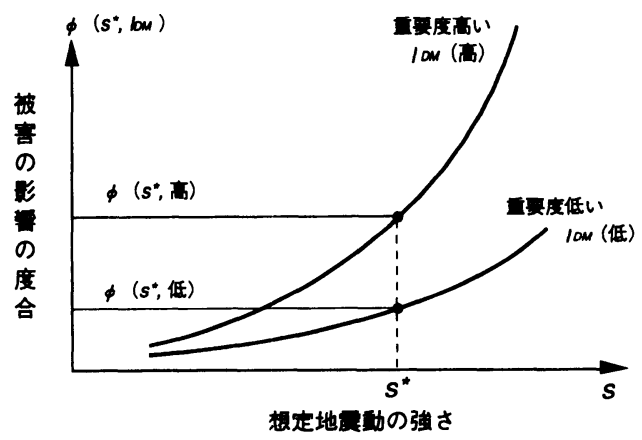

図一1想定地震動の強さ，重要度と被害影響の度合いの関係

勘案して対策の優先順位や対策のレベルを決めていくこ とになるが, この論文では重要度にしぼって, その意味 や対策計画を立てる際の有用性を明らかにする.

今, ある橋 $i$ が被災した場合の影響の度合いを $\phi_{i}$ と すると, $\phi_{i}$ は地震動の強さ $s$, 橋の耐震性（ないしは耐 震脆弱性） $v$ およびその橋の重要度 $I_{D M}$ によって決定さ れる. すなわち， $\phi_{i}\left(s, v, I_{D M}\right)$ と表わされる。ただし， 本論の以下では簡単のため, 橋の耐震性 $v$ は一定と考え, $\phi_{i}\left(s, I_{D M}\right)$ と表記する (図一1). 影響の度合い $\phi_{i}$ は, その橋が被災することによる直接的な影響ばかりでな く, 道路網あるいは様々な都市機能への影響の度合いを も含むものである，一般に影響の度合い $\phi_{i}\left(s, I_{D M}\right)$ は， 地震動 $s$ が強いほ亡゙，その橋の重要度 $I_{D M}$ が高いほど大 きい.

対策計画を立てる際には想定する地震を設定する。こ の場合の地震動の強さを $s^{*}$ とすると, 図一1 加ら重要 度 $I_{D M}$ と影響の度合い $\phi_{i}$ の関係は図一2（a ）のように なる．各々の橋の重要度は3. で述べる方法により評価 されるが，ある都市における橋の重要度の頻度分布はた とえば図一2（b ）のようになる．地震動強さの想定値 s*に対して, 都市全体の影響の度合いは, たとえば, 式（1）で表され，耐震対策計画は，この值 $\phi$ と対策 の目標値 $\phi^{*}$ の差 $\left(\phi-\phi^{*}\right)$ を可能なかぎり低減, ない しは理想的にはゼロにすることである.

$$
\phi=\sum \phi_{i}\left(s^{*}, I_{D M}\right)
$$

ここで $\left(\phi-\phi^{*}\right)$ をどのように低減させていくかが問 題となる.ひとつは震前対策 (予防対策) と震後対策 (応 急対策等）を適切に組み合わせて目標を達成することで ある. 両者は相互に補完する関係にあり, 震前対策が遅 れるようであれば，その分，震後対策を充実させていく. もう一つは, 対策の優先順位を考慮して対策の効果を早 期に高めていく考え方である．この考え方は震前対策， 震後対策および両者の組み合わせにも適用しうるが，こ こでは簡単のため震前対策を例にとって説明する.

対策計画の目標は先の $\left(\phi-\phi^{*}\right)$ をある目標年数 $T^{*}$

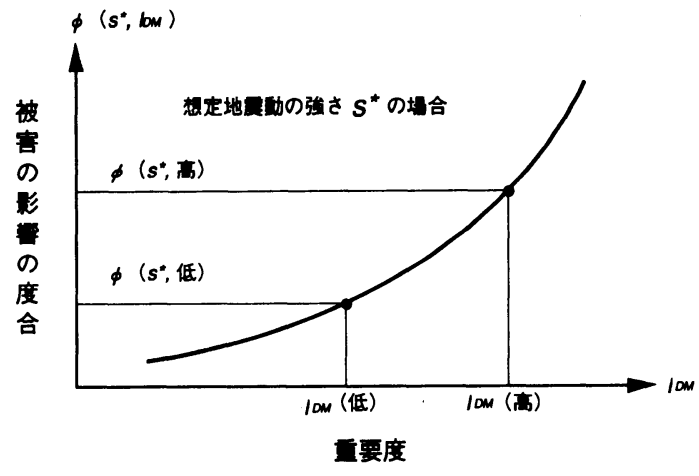

( a ) 重要度と影響の度合い

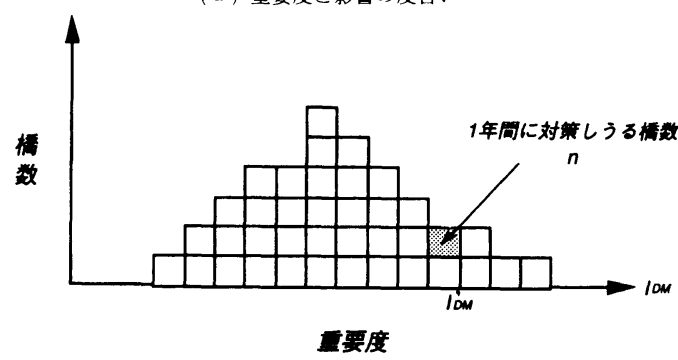

(b ) 重要度の分布と年間に対策しうる橋数

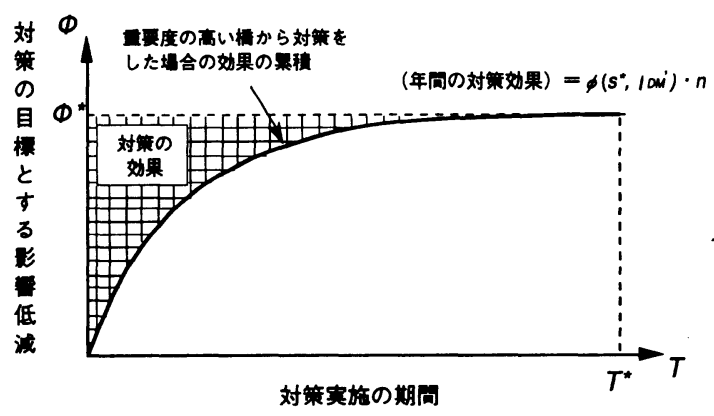

(c) 目標年数に対する対策効果の累積

図一2 想定地震動 $s *$ の場合の重要度に基づく対策達成および 効果の概念

で達成することであるが，震前対策には膨大な費用と時 間がかかるため，必然的に制約条件が付される，すなわ ち，図一2（b）に示すように 1 年間にある一定数の橋 しか対策を施せない，もちろん，対策は，たとえ重要度 が低くとも全ての橋に対して施す必要がある.このよう な制約条件をつけると， $T *$ 年間の間に，毎年どの橋を 選んで対策を進めていけば総合的にみて効果がより大き くなるかという問題になる.年間における対策の効果は, ある重要度 $I_{D M}$ ，の橋を年間 $\boldsymbol{n}$ 橋対策するとすると少な くとも $n \cdot \phi\left(s^{*}, I_{D M}\right)$ と表すことが出来る（図-2（b ）, (c ) 参照).この時, 地震の発生確率が $T^{*}$ 年間で一定 という条件をつけると, 被害の影響の度合いの大きい橋, すなわち重要度の高い橋から対策を施していくのがよい 


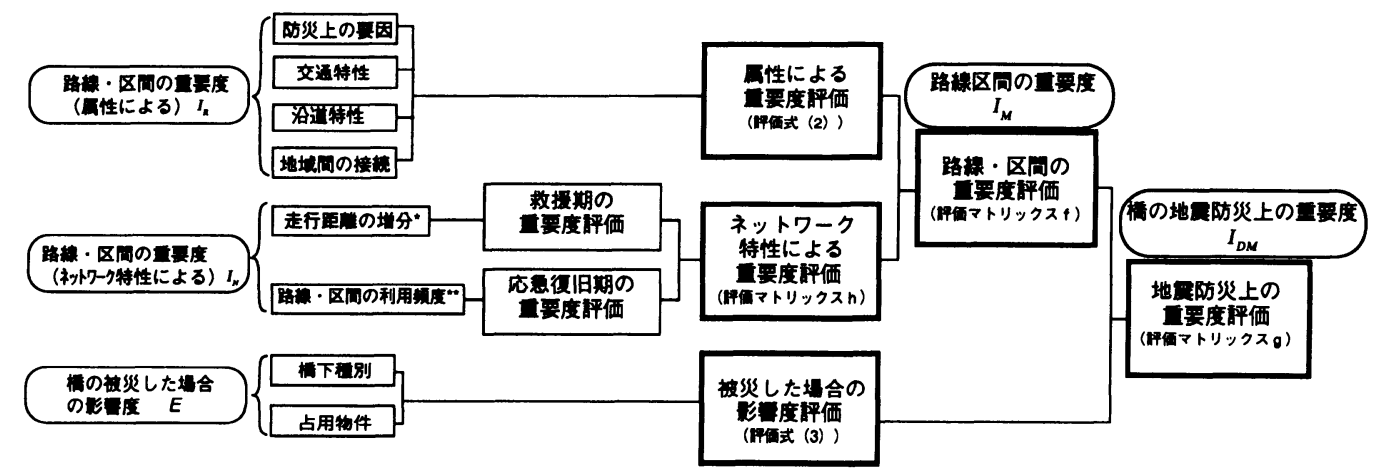

*ある路線・区間が通行止めとなった渽合の主要拋点間の走行距非の增分

**主要数点間交通における各路線・区間の利用頗度

図一3 大都市における道路橋の地震防災上の重要度の評価・分類の手順

表一 1 橋の地震防災上の重要度 $I_{D M}$ の評価マトリックス $g$

\begin{tabular}{|c|c|c|c|c|}
\hline & & \multicolumn{3}{|c|}{ 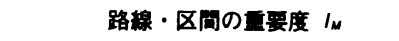 } \\
\hline & & 最直要 & 曋要 & 一般 \\
\hline $\begin{array}{l}\text { 被 } \\
\text { 炎 }\end{array}$ & 柤めて & & & \\
\hline 合 & 大きい & & 量要 & \\
\hline 度 & 一般 & & & 一般 \\
\hline
\end{tabular}

ことは明らかである，たとえば，図一2（a ）（b）で 重要度の高い方の橋から対策していくと，対策効果の年 ごとの累積は図一2（c）に示すようになる．どのよう に対策を進めていくかの方法の良否はこの累積曲線の補 面積で評価することができ，重要度に応じた対策の実施 が合理的であることが理解できよう.

\section{3. 橋の重要度評価モデル}

橋の地震防災上の重要度の評価に際して，2つの指標 を考える. 1 つは，道路ネットワーク全体から橋梁の位 置する路線・区間を見た場合の重要度であり，もう $1 つ$ は橋が被災した場合の機能低下・周辺施設への被害波 及・利用者の人命に与える影響などの大きさを総称した 影響度である．以下では，橋の地震防災上の重要度を $I_{D M}$, 橋の位置する路線・区間の重要度を $I_{M}$, 橋が被災 した場合の影響度を $E$ とする．2つの指標のうち $I_{M}$ は， 防災上の要因・交通特性・沿道特性・河川の横断状況な ごの要因属性から評価した相対的な重要度 $I_{R}$ と交通の 利用頻度などのネットワーク特性に基づく重要度 $I_{N}$ の 2 つの指標の組み合わせによって評価する. 影響度 $E$ は対象となる橋の析下の利用状況および添架してある占

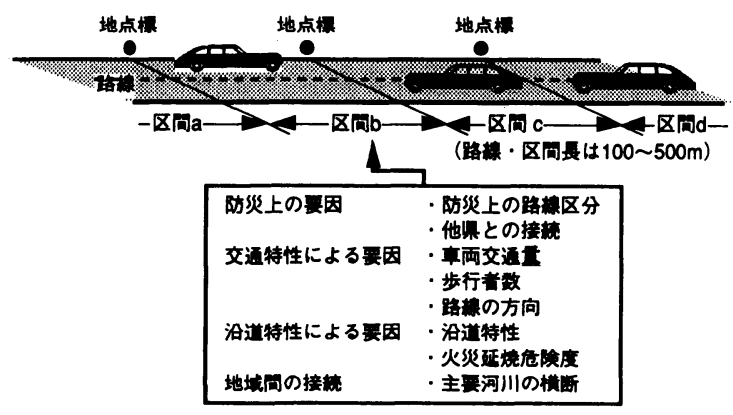

図一4 路線・区間と評価属性

用物件の状況の 2 つの要因から評価する.

最終的に，橋の地震防災上の重要度 $I_{D M}$ は，表一1に 示すように指標 $I_{M}$ と $E$ を，それぞれ 3 段階に区分した 評価マトリックス $g$ から決定する。

図一 3 に橋の地震防災上の重要度 $I_{D M}$ の評価のフロー チャートを示す.

\section{（1）路線・区間ごとの重要度 $I_{M}$ の評価}

路線・区間の総合的な重要度評価のために，各種の属 性から評価した重要度 $I_{R}$ と交通ネットワーク特性に基 づく重要度 $I_{N}$ の両面から評価する.

属性に基づく路線・区間の重要度 $I_{R}$

図一4に示すように対象とする路線に 100〜 $500 \mathrm{~m}$ の 間隔で地点標を設け，これらの地点標間に防災上の路線 区分・交通特性に関する要因・沿道特性に関する要因お よび河川の横断状況等の要因属性を付与する.これらの 属性 $j$ を評点 $X_{j}$ で表わすとともに，それらの各属性に 対して重み係数 $W_{j}$ を乗じたものの総和を求め，その大 小により重要度の評価を行う．従って，ある路線・区間 の重要度の点数は式（2）で表わされる.

$$
I_{R}=\sum_{j=1}^{n} W_{j} \cdot X_{j}
$$


ここに,

$I_{R}:$ 対象とする路線・区間の重要度の点数

$W_{j}:$ 属性 $j$ の重み係数

$X_{j}:$ 属性 $j$ に対する評点

この $I_{R}$ の值が大きいほど重要度は高いものとし, す べての対象区間の評点のヒストグラムから相対的な重要 度を最重要, 重要, 一般に区分する。

図一4に示した 4 つの要因についての評価の考え方は 次のとおりである.

防災上の要因としては, 災害対策基本法に従って各自 治体が定めた防災上の路線区分と他県との接続状況を考

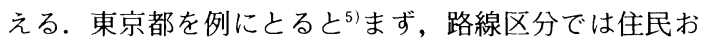
よび道路通行者の避難や救援活動に使用される避難道路 の評点を最も高くし, 緊急輸送路ネットワーク, 緊急啓 開路線等をこれに次ぐ重要な路線とする. また，他県と 接続している路線・区間や港湾地域の防災埠頭之連結す る路線についても援助活動に重要な機能を果たすため, 評点を高くすることが考えられる.

交通特性による要因としては, 車輛交通量, 歩行者数 および路線の方向を考慮する，車輛交通量は，大都市の 交通特性を端的に表わす平日 12 時間の上下線合計の大 型車輛数とする. 格子状の道路網と異なり, 東京都のよ うな放射状線と環状線で構成された道路網では, 放射状 線の間の移動には環状線を経由せざる得ない。このため, 路線の方向については, 放射状線よりも環状線の評点を 高く設定する.

沿道特性に関する要因としては, 土地利用状況と火災 延焼危険度を考慮する.土地利用では, 地震時の被害の 影響が大きい繁華街やオフィス街などの評点を高くす る. 火災延焼危険度については, 地域防災計画の一環と して別途実施されている地域危険度の評価に用いられる 火災危険度6ををとに，評点を設定する．

河川の横断は, 防災上の路線区分と並ぶ最も重要性の 高い要因である. 都市域において, 主要な河川に架かる 橋の破損は地域の分断を引き起こし, 避難・救援・復旧 活動にも支障をきたす。このような状況判断と既往の研 究成果》薄えて, 川幅 $50 \mathrm{~m}$ 以上の河川を横断する路 線・区間をきわめて重要な区間として評点を与える.

路線・区間のネットワーク特性に基づく重要度 $I_{N}$

ネットワーク特性に基づく重要度は, 発災直後, 救援 期 (震後概ね $2 \sim 3$ 日後程度), 応急復旧期 (震後 1 週間 程度）なざの段階で評価すべきであろう。また，その際 に考慮すべき要因は，此較的マクロな道路網を対象亡し た道路の利用状況, 移動方向・量, 交通の特徴等が考え られる.

まず, 震後の段階のうち発災直後については, 大都市 の道路密度が高いため, 橋の被害のみで孤立地区が現れ ることは考えにくい.さらに, 避難行動が主で個々の移

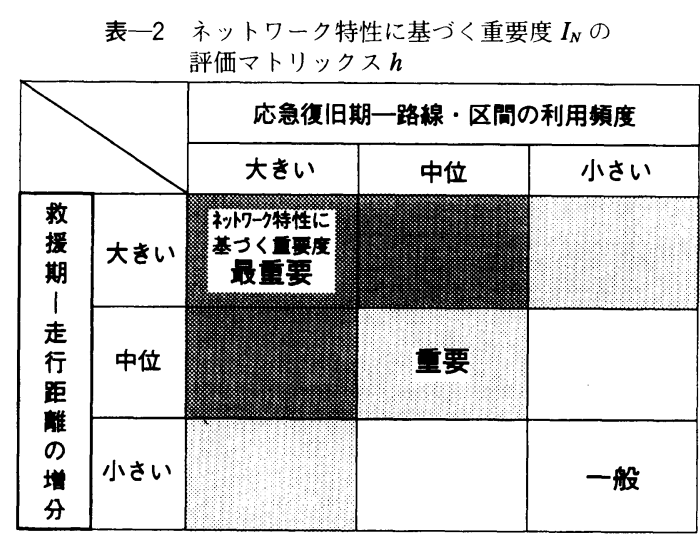

動のトリップ長が短いため, ネットワークとして道路の 機能を評価することは適切ではない。したがって, 本論 文ではネットワーク特性に基づく重要度の評価は, 救援 期と応急復旧期を対象とする.

各段階における評価の尺度としては, 救援期には任意 の交通が所定の時間内に達成できること（確実性）が重 要であるため, 各路線・区間が任意の最短交通の走行時 間に寄与する貢献度を評価するのが望ましい，しかしな がら, 各地点間の交通の許容所要時間を設定することが 難しいため, 本研究では着目する路線・区間が利用でき ないとした場合の各主要拠点間の走行距離の增分（主要 拠点間の増分の総和）を求め, この相対的な比較によっ て重要度を 3 段階に評価する。一方, 応急復旧期におい ては上記の確実性に加えて, 大量の物資の輸送が行える こと（確実性+大量性）が重要であるから, 主要拠点間 交通における各路線・区間の利用頻度を評価する．ただ し, 各地点間の,震後の交通量を把握することが困難なた め, 主要拠点間において単位の交通を仮定し, これらが 最短経路を通過する場合の各路線・区間の通過回数（利 用頻度）をカウントし, その利用頻度の相対比較によっ て重要度を 3 段階に評価する. より具体的には, よ゙の路 線区間も被災していない健全なネットワークについて, 全ての主要拠点間に単位の交通を割りあて(最短経路), その交通の束の太い路線・区間がより重要と考える.

上記の 2 つの評価手法に従って, 各路線 - 区間の重要 度を評価し, 最終的に表一2に示す評価マトリックス $h$ からネットワーク特性に基づく重要度 $I_{N}$ を決定する.

\section{路線・区間の重要度 $I_{M}$}

路線・区間の属性から求めた重要度 $I_{R}$ とネットワー ク特性から得られた重要度 $I_{N}$ を, 表一 3 の評価マトリッ クス $f$ に当てはめ, 路線・ 区間の総合的重要度 $I_{M}$ を判 定する. 結果は, 最重要, 重要, 一般の 3 段階に区分す るが, 表一3 (1つの例) の場合には, $I_{N}, I_{R}$ の各々の 最重要に重きをおいた評価としている. 
表一3 路線・区間の重要度 $I_{M}$ の評価マトリックス $f$

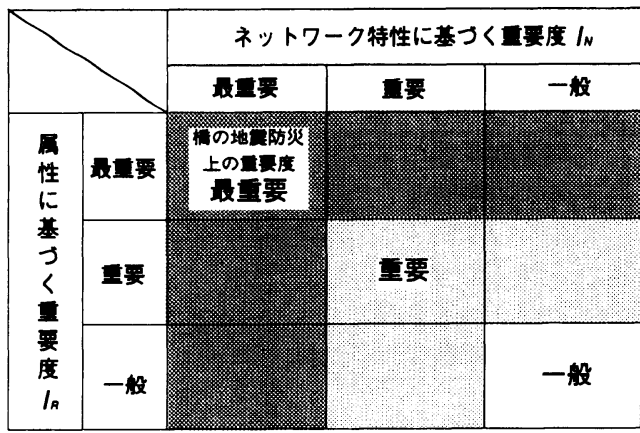

\section{（2）橋の被災した場合の影響度 $E$}

落橋もしくは下部工に大規模な変状を生じるなどの被 害を受けた場合の波及効果の大小により，その影響の程 度を評価する．考慮する要因は桁下の利用状況（橋下種 別), 橋に添架されている占用物件の種類, 数, その重 要性なよ゙である.

橋下種別では被害波及の大きさから，橋下が鉄道・道 路の場合に着目する．橋下の鉄道は，複線の旅客線，単 線の旅客線，貨物線の順番で影響度の評点が高くなるよ うにする．一方，橋下種別が道路の場合，被災した場合 の影響度は道路の交通量によって評価すべきであるが， ここでは前述した路線・区間の重要度を代替的に用いて 評点を設定する.

占用 (添架) 物件については, 水道・電気・電気通信 · ガス等の種類別の評価は行わず，各々の幹線について複 数添架・単数添架など占用状況の違いによる評点付けを 行った.

上記の 2 つの要因の評点を, 個々の橋ごとに決定し, それらの評点に対して重みの係数を乗じたものの総和に より影響の大小を表わす。したがって，ある橋の影響度 の点数 $E$ は次式で表わされる.

$$
E=\sum_{k=1}^{m} \delta_{k} \cdot Y_{k}
$$

ここに,

$E$ : 対象とする橋の被災した場合の影響度の点数

$\delta_{k}$ : 要因 $k$ の重みの係数

$Y_{k}$ : 要因 $k$ の評点

この点数 $E$ が大きいほよ゙，橋の被災した場合の影響 が大きいことを意味する．対象橋梁のすべての影響度点 数のヒストグラムから，影響の程度を極めて大きい，大 きい,一般の 3 段階に区分する.

ここで提案した重要度の評価モデルを適用する場合,

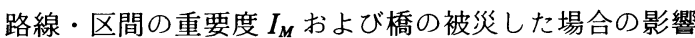
度 $E$ の算出に必要となる各種要因の評点と重みの係数 の值によって評価の結果が大きく変わる.このため,こ
表一4 事例解析で用いた要因の評点・重みの一覧表 (路線・区間の重要度 $I_{R}$ )

\begin{tabular}{|c|c|c|c|c|c|c|}
\hline & & 要 & 战 点 & & $W_{1}$ & (31例) \\
\hline & & & & 1 & 2 & 3 \\
\hline & & 避散道路 & 3 & & & \\
\hline 防 & 防災上の & 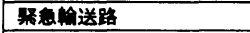 & 3 & 10 & 5 & \\
\hline 资 & & 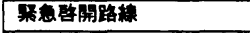 & 2 & 10 & 0 & 8 \\
\hline$\frac{1}{\sigma}$ & & その他 & 1 & & & \\
\hline $\begin{array}{l}\text { 覀 } \\
\text { 因 }\end{array}$ & $\begin{array}{l}\text { 他基との } \\
\text { 接繶 }\end{array}$ & $\begin{array}{l}\text { 埼玉 ·千菜 } \\
\text { 神奈川·山梨 }\end{array}$ & 2 & 5 & 5 & 4 \\
\hline 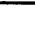 & & 4,000台以上 & 3 & & & \\
\hline & 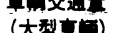 & 1,300台以上 4,000 台末消 & 2 & 4 & 5 & 3 \\
\hline & 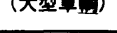 & 1,300人未滥 & 1 & & & \\
\hline 交 & & 3,000人以上 & 3 & & & \\
\hline 遜 & 步行菌数 & 1,500 人以上 3,000 人末浻 & 2 & 3 & 5 & 2 \\
\hline 恃 & & 1,500人末溯 & 1 & & & \\
\hline & & 主要な列状線 & 3 & & & \\
\hline & 路綠の方向 & 主要な放射状穆 & 1 & 3 & 5 & 2 \\
\hline & & その他 & 0 & & & \\
\hline & & 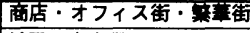 & 3 & & & \\
\hline 沿 & 沿道特性 & 低雷－中早眉 & 2 & 2 & 5 & 6 \\
\hline 逆 & & 田国-山岳·河川・堤防 & 1 & & & \\
\hline 特 & & ランク 5 & 3 & & & \\
\hline 性 & 火災延烧 & ランク 3， 4 & 2 & 3 & 5 & 6 \\
\hline & & ランク1， 2 & 1 & & & \\
\hline & 主要河川の & 主要河川を栱断する区問 & 3 & 10 & 5 & 9 \\
\hline & 栱断 & 上E以外 & 0 & & 5 & \\
\hline & 合 & & & 40 & 40 & 40 \\
\hline
\end{tabular}

防災上の路緗区分

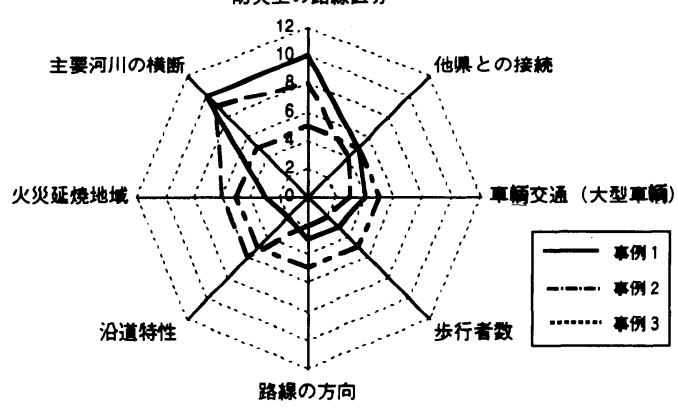

図５各事例で用いた重み $\left(W_{i}\right)$ のレーダーチャート

れらの係数, 評点の值に複数のパターンを用意し，それ ぞれのケースについて， $I_{M}$ と $E$ を算出し，防災上の重 要度の分類を試みる．耐震保全対策の計画策定にあたつ ては，日常管理を担当している熟練技術者の判断に委ね て，最も妥当と判断されるケースの値を採用する.

\section{4. 適用例}

提案した手法の有効性を検討するために，東京都建設 局の管理する橋梁のうち，23 区および多摩地区に位置 する約 1,000 橋を対象として事例解析を行った。

\section{（1）属性に基づく路線・区間の重要度 $I_{R}$ の評価}

事例解析で用いた属性の評点と重み係数の値を表一4 に示す (各々式 (2)の $X_{j}, W_{j}$ ).

この中で，道路の防災上の路線区分は，前述の趣旨に 


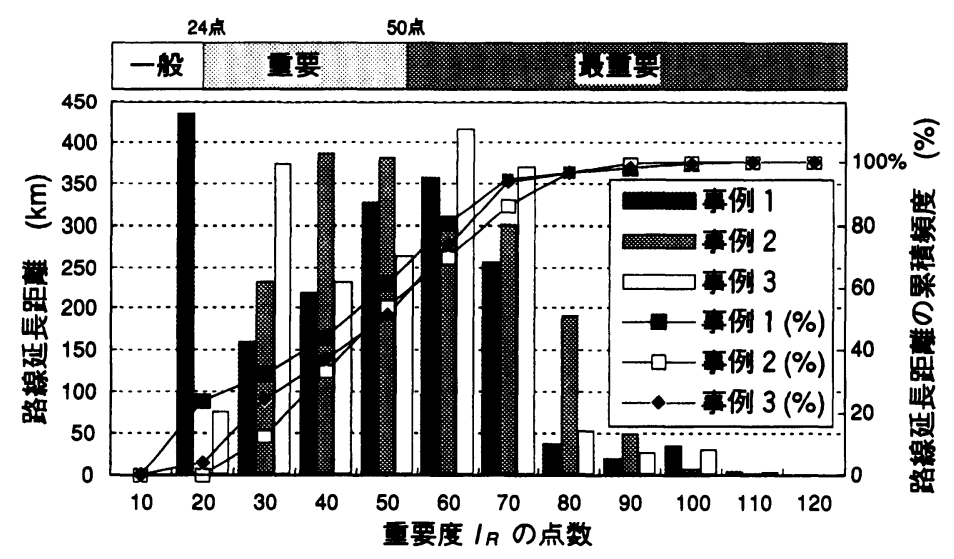

図一 属性基づく路線・区間の重要度 $I_{R}$ の点数分布

従って避難道路・緊急輸送路ネットワーク・緊急啓開路 線の 3 種類とし ${ }^{5}$, 各路線・区間の評点を決定した。他 県との接続については，関東一円に大きな被害をもたら す大規模地震を想定したために，他県と接続する各路 線・区間の評点を一律とした．東京湾の防災埠頭と連結 する路線についても，この例では考慮しなかった。

交通特性の大型車輌交通量と歩行者数に関する評点 は, 東京都建設局が所有する平日 12 時間の上下線合計 のデータ8)をもとに決定した，沿道特性に係わる要因に ついては, 各路線・区間の上下線の沿道状況を東京都道 路構成調書' た。灭災延焼危険度は，東京都地域危険度 ${ }^{61}$ に示された

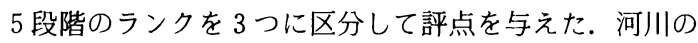
存在による隣接地域間の接続性については, 川幅 $50 \mathrm{~m}$ 以上の河川に架かる橋をきわめて重要な路線・区間亡 し, 江戸川, 旧江戸川, 中川, 新中川, 旧中川, 荒川, 新河岸川, 隅田川, 多摩川 (羽村取水堰, 羽村大橋上り 下流), 浅川 (八王子荻原橋より下流) を対象とした.

表一 4 に示すように，事例解析は重み係数を変化させ た $3 つ の$ 事例に関して行った. 各事例の重み係数の採用 に際しては，道路管理に携わる専門技術者の意見を反映 させているが, 特に事例 2 では全ての要因の重みを一律 とし, 事例 3 では都市部の路線機能に着目するために沿 道特性や火災延焼危険度の重み係数を高く設定した。各 事例の要因ごとの重み係数を, 図一5 のレーダーチャー トに示す.

以上の条件を用いた解析で得られた結果を図一6，7 に示す. 図一6は, 評価式 (2) 加各路線・区間の重 要度の点数を求め, 重要度の点数ごとの路線延長距離 （m）亡路線延長距離の累積比率（％）を示したもので ある.前述のように,本方法では重み係数の与え方によっ てこの分布は変化するために絶対的な評価は困難であ る.そこで，この評価のために新たに開発した道路地図
情報システム（図一7９など）に重要度点数の分布状 況を表示し，環状線と放射状線の点数が相対的に高くな ること,区部に点数の高い路線が集中して現われること， さらには専門家の目から見て点数分布のバランスがよい ことを確認して，事例 1 の重み係数が他の事例に比べて 妥当亡判断した。なお，图一6を用いて重要度を 3 つに 区分する際には，緊急輸送路ネットワークに指定されて いる路線, 特に環状七号線全線が「最重要」の路線とな るように設定し，「一般」の路線の上限値は図一6のヒ ストグラムの谷で設定した．図一7は，3つに区分され た重要度を対象路線全てについて図示した結果である (事例 1)。これから, 評点, 重みの設定で意図した通り, 区部の主要路線, および多摩地区の骨格をなす路線が最 重要ないしは重要路線として抽出されていることがわか る.

\section{（2）ネットワーク特性に基づく重要度 $I_{N}$ の評価}

ネットワーク解析では，（1）で用いた全路線・区間 を対象とし, 約 700 のノードからなるネットワークを用 いた。これらのノードの中から各区庁舎の所在地, 都が 指定する陸上・海上・航空 - 水上輸送基地, 道路の都県 境界など主要な 112 地点（主要拠点）を選定しこれら を交通の起終点（OD 点）とした.

救援期を対象としたネットワーク解析では, 着目した 路線・区間が使用できないときの全 OD 点間の走行距 離の増分の総和を求めた。.応急復旧期については, すべ ての OD 点間で最短経路を通過する単位の交通量を仮 定して対象路線・区間の通過回数の総和を求めた。救援 期, 応急復旧期各々の点数に基づき, 表一 2 に示すよう に重要度を大・中・小に区分した．これらの区分は，先 の属性によるものと同様, 点数の分布から主観的に決定 したものである.

救援期においては，最短経路としての各路線・区間の 


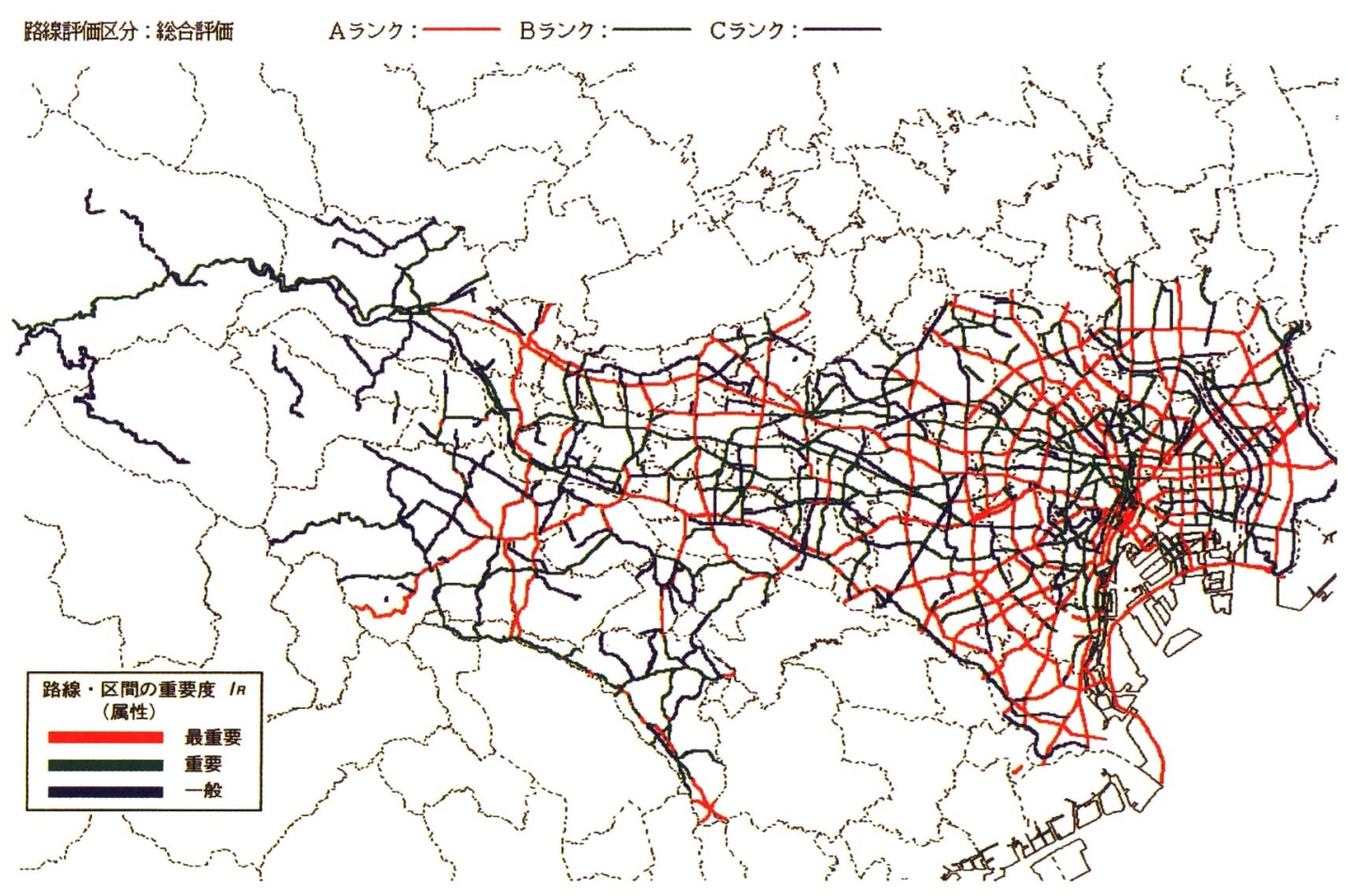

図一7 属性に基づく路線・区間の重要度 $I_{R}$ の評価結果（事例 1）

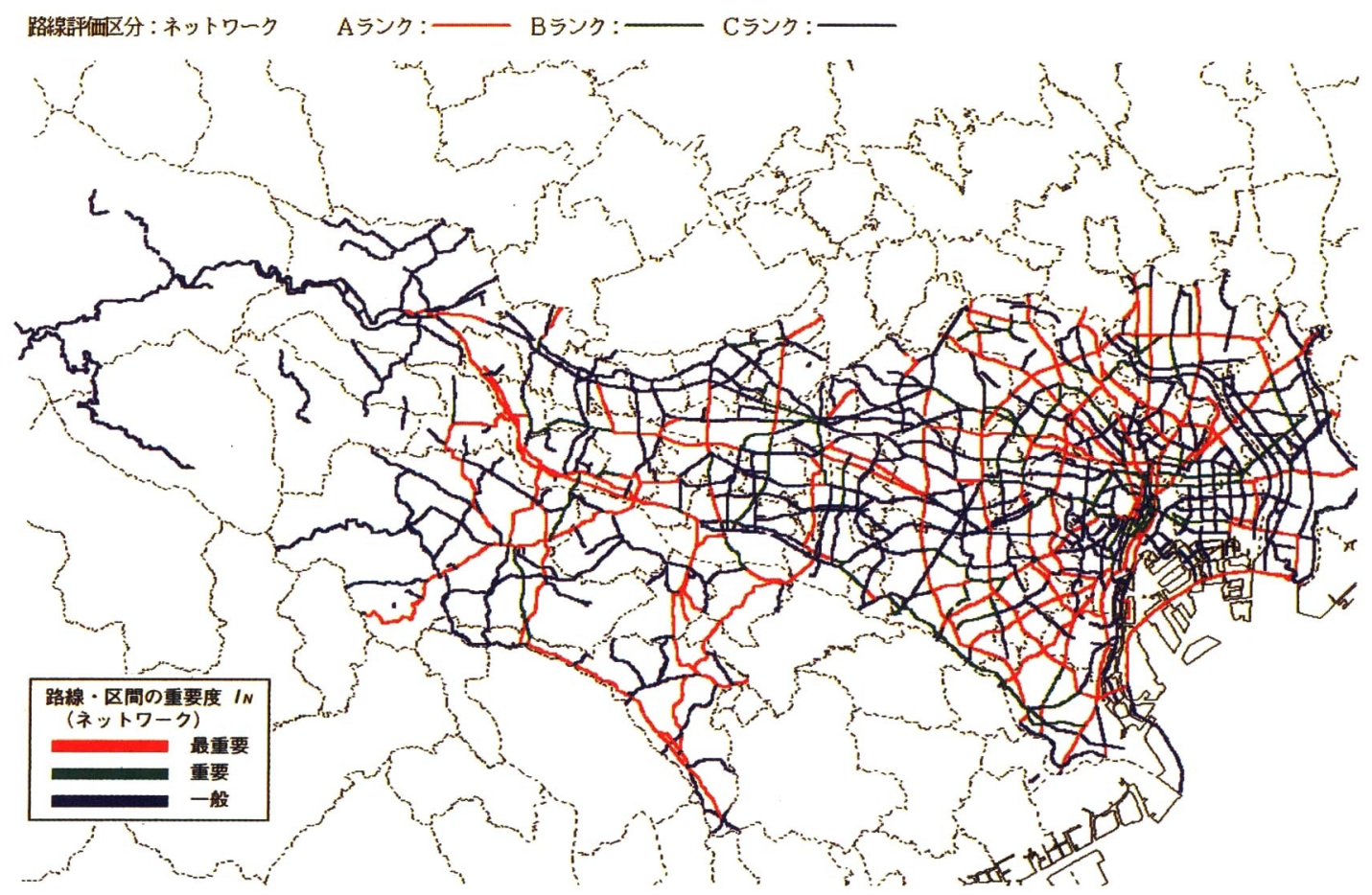

図一8 ネットワーク特性に基づく路線・ 、間の重要度 $I_{N}$ の評価結果 


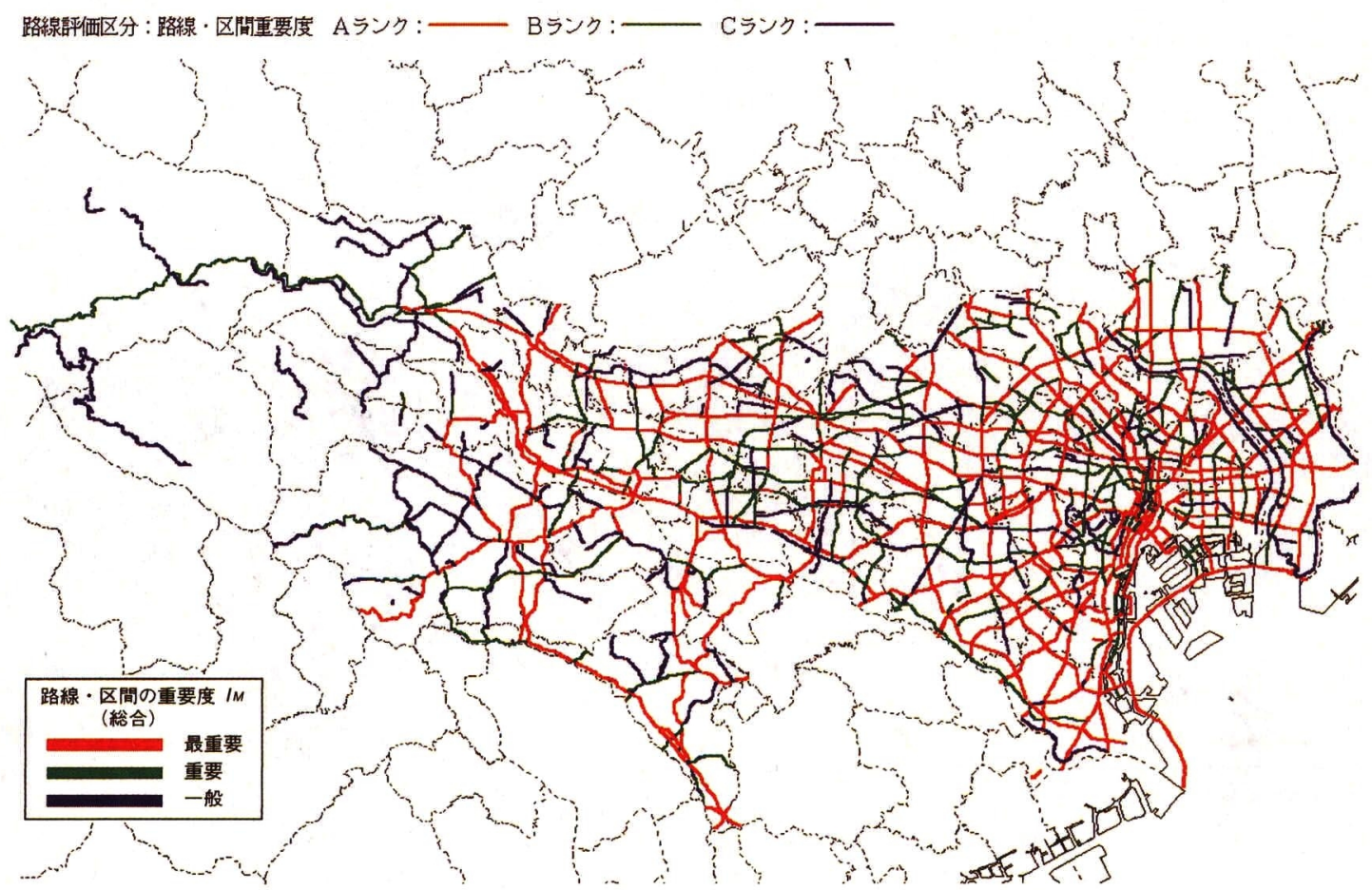

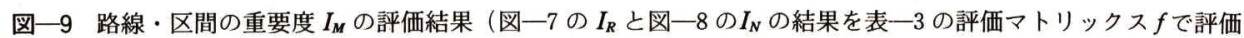

表一5 事例解析で用いた影響度 $E$ の要因の評点と重みの一覧 表

\begin{tabular}{|c|c|c|c|c|c|c|}
\hline & & & 砰点 & $\overline{1}$ & $\delta_{k}$ & \\
\hline & & 要 & $Y_{k}$ & $a$ & $\mathrm{~b}$ & c \\
\hline & & 族客線（被被線） & 3 & & & \\
\hline & 道 & 旅客線（単線または椱線） & 2 & 10 & 7 & 10 \\
\hline 下 & & 寞物楾 & 1 & & & \\
\hline 䆄 & & 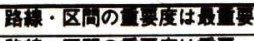 & 3 & & & \\
\hline 別 & 路 & 路楾・四の要度は要 & 2 & 5 & 7 & 3 \\
\hline & & その他 & 1 & & & \\
\hline & & 被数添架 & 3 & & & \\
\hline & - & 単一添架 & 2 & 6 & 7 & 8 \\
\hline & & 無 & 1 & & & \\
\hline
\end{tabular}

貢献度が評価されるため, 主要な環状線や放射状線の増 分が大きく，応急復旧期においては，最短経路として利 用頻度の高い一部の放射状線の増分が大きくなった.

以上の結果を評価マトリックス $h($ 表一2) により総 合評価し，ネットワーク特性に基づく重要度 $I_{N}$ を図示 したものが図一8である. 神奈川県に゙近い地域と千葉に 近い一部を除いて, 環状線と主要な放射状線の重要度は 相対的に高く,概ね現実に近い妥当な結果と考えられる.

\section{（3）路線区間の重要度 $I_{M}$ の評価}

属性に基づく重要度 $I_{R}$ (事例 1 ）とネットワーク特性 に基づく重要度 $I_{N}$ を, 評価マトリックス $f($ 表一3）に 当てはめて路線・区間の重要度 $I_{M}$ を評価した。結果を 図一9に示すが, 属性のみの結果 (図一7) と比べ, 重
要路線のネットワーク的な特性が補強され, 全体として の重要度のバランスがより妥当なものになっていること がわかる.

\section{（4）橋の被災した場合の影響度 $E$ の評価}

事例解析で用いた要因とその評点, 各要因の重み係数 を表一 5 に示す (各々式 ( 3 ) の $Y_{k}, \delta_{k}$ ). 評点は, 影 響度の大きい要因の属性から順に $3,2,1$ 点を与えた. 重みについては, 専門家の意見を参考に $\mathrm{a}, \mathrm{b}, \mathrm{c}$ の 3

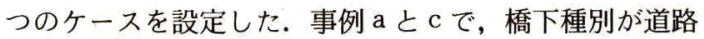
のときの重みを鉄道のそれよりも小さくしたのは, 東京 都の道路立体交差には必ず側道があり, 万一落橋した場 合でも側道による緊急輸送機能がある程度確保されると 考えたことによる.

以上のような条件で影響度を計算した結果を図一10, 11 に示す. 図一10 は, 橋の被災した場合の影響度の点 数を評価式 ( 3 ) から求め, 点数ごとの橋梁数とその累 積頻度を図示したものである.この計算では，橋下の道 路の重要度として, 前述の路線 - 区間の重要度 $I_{M}$ (事 例 1) を用いた. 事例 $a, b, c$ では, 影響度の点数の高 い方で違いがでてくるが,頻度分布および累積曲線から, 事例 a が最もバランスがよいことがわかる. 事例 a をと りあげ対象とする橋梁の影響度の点数を道路地図情報シ ステム上で比較検討した結果から，図一10に示すよう 


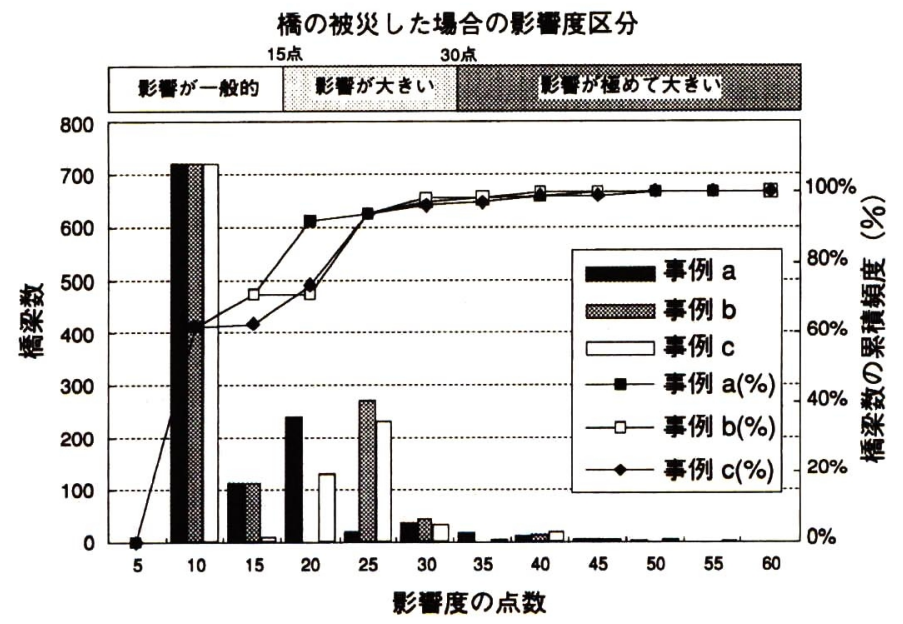

図一10 橋の被災した場合の影響度の点数分布

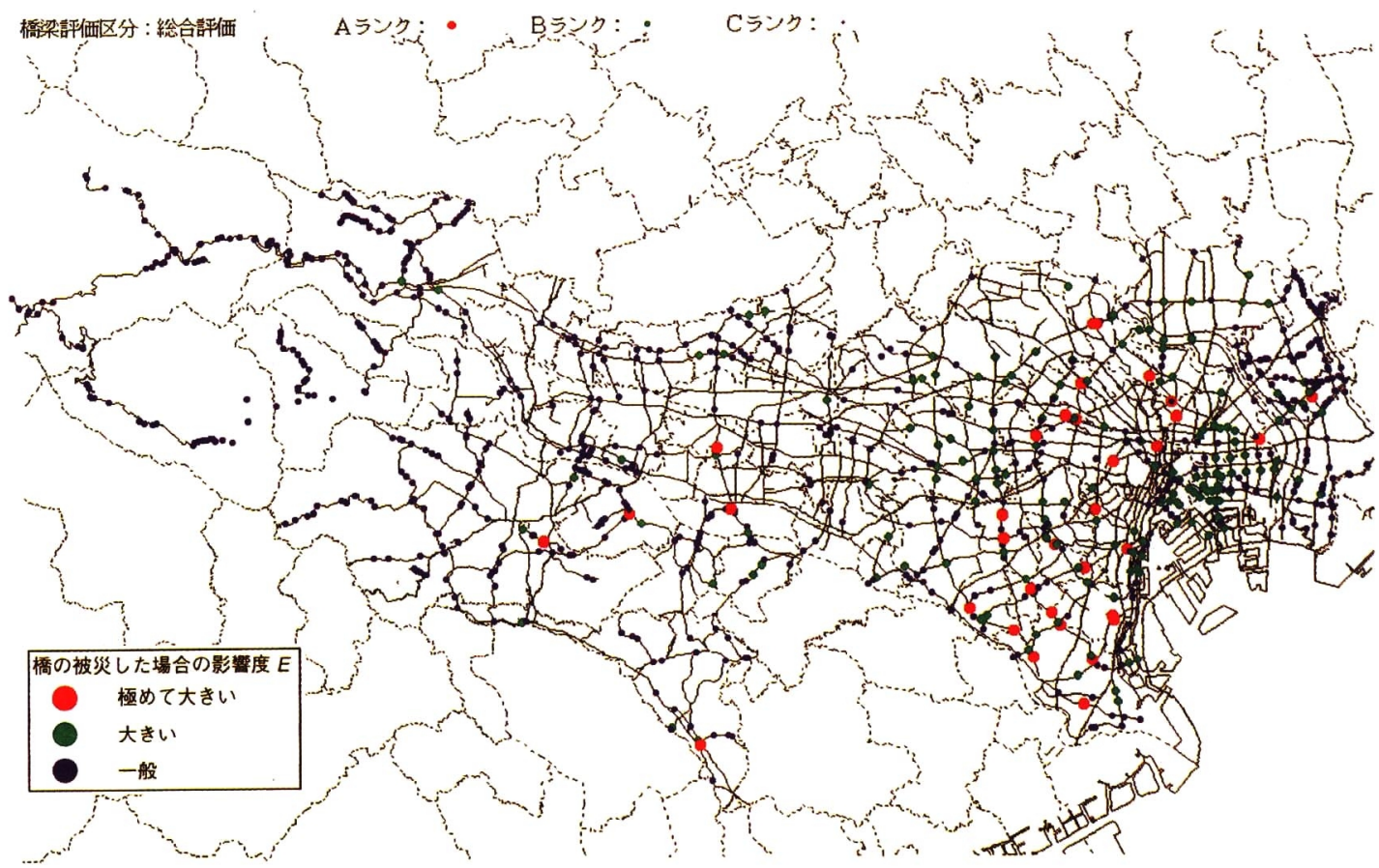

図一11 橋の被災した場合の影響度 $E$ の評価結果（事例 a )

に影響度を 3 つに区分した．図一11に事例 a の場合の 全橋梁の影響度を区分した結果を示す．影響度が “極め て大きい”と区分された橋は大部分鉄道 (旅客複線以上) をわたる橋である．環状線，放射状線では主要な道路を わたる陸橋が，都心部および下町地区では重要な添架物 件を持つ橋が影響度が“大きい”と区分されている。

\section{（5） 橋の地震防災上の重要度 $I_{D M}$ の評価}

路線・区間ごとの重要度 $I_{M}$ と橋の被災した場合の影
響度 $E$ を評価マトリックス $g$ (表一 1$)$ に当てはめて得 られた, 橋の地震防災上の重要度 $I_{D M}$ を図一12 に示す. また, 表一6には $I_{D M}$ の 3 段階に該当する橋の数を示す. これらの結果から，以下のような傾向を読み取ることが できる.

•23 区部では「最重要」,「重要」の橋の占める割合が 高いのに対して多摩地区では「一般」に分類される橋 が多い.

・ 区部の環状線の陸橋あるいは環状線と交差する陸橋が 


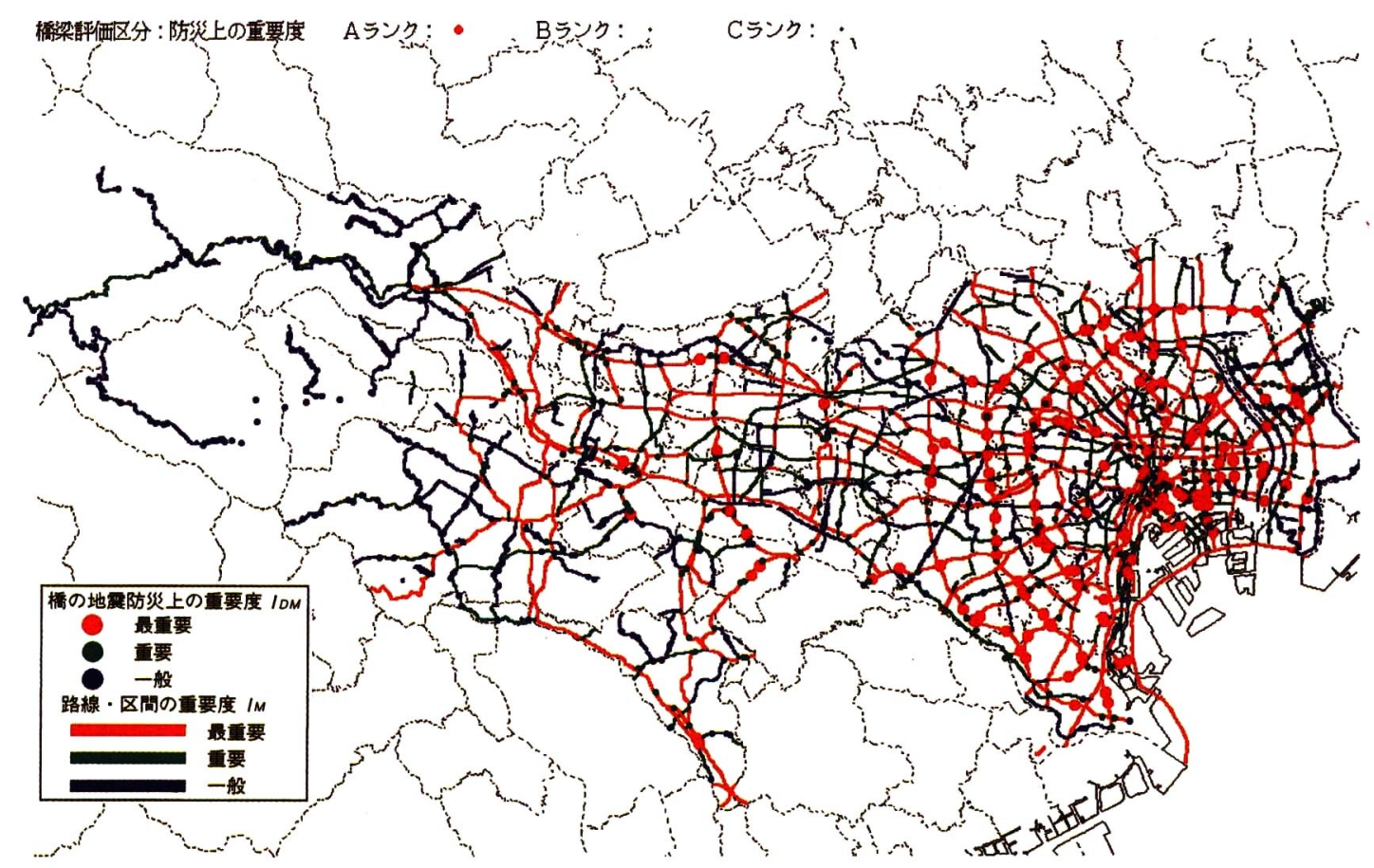

図一12 橋の地震防災上の重要度 $I_{D M}$ の評価結果（図一9の $I_{M}$ と図一 11 の $E$ の結果を表一 1 の 評価マトリックス $g$ で評価)

表一 6 橋の地震防災上の重要度 $I_{D M}$ の区分結果 （）内は対象橋梁数に対する比率\%)

\begin{tabular}{|c|c|c|c|}
\hline $\begin{array}{l}\text { 地 } \\
\text { 地域 } \\
\text { 防曻上 } \\
\text { D重要度IDM }\end{array}$ & 23区部 & 多摩地区 & 合 計 \\
\hline 最重要 & $137(13.4)$ & $10(1.0)$ & $147(14.3)$ \\
\hline 重 要 & 199 (19.4) & $64(6.2)$ & $263(25.7)$ \\
\hline 一 般 & $175(17.1)$ & 440 (42.9) & $615(60.0)$ \\
\hline
\end{tabular}

大部分最重要と区分される.

・多摩地区で「最重要」と区分される橋は影響度の大き い橋およびこれに加えて多摩の道路ネットワークの基 幹となる路線の橋である.

\section{5. あとがき}

本研究は，既設道路橋の合理的な耐震保全対策事業の 実施計画策定を念頭において, 橋の地震防災上の重要度 の概念と有効性を示すとともに，その評価手法を新たに 提案したものである. 論文の内容を以下に要約する.

（1）既設の橋の耐震対策計画を立案する上で，重要 度の概念が有効であることを示した．耐震補強対策（震 前対策）を例にとれば，年間に対策しうる橋の数が限ら
れるという制約条件のもとで，重要度に応じて優先順位 を定め対策を実施していくことで高い効果が得られる.

（2）道路の特性を表す各種要因やネットワーク特性 から評価した路線・区間の重要度 $I_{M}$ と, 橋の被害にと もなう影響度 $E$ とを組合わせた評価によって，橋の地 震防災上の重要度 $I_{D M}$ を決定する方法を提案した． 路 線・区間の重要度 $I_{M}$ については，路線・区間の属性に 基づく重要度 $I_{R}$ と道路のネットワーク特性に基づく重 要度 $I_{N}$ の組合わせによって評価し，橋の被災した場合 の影響度Eについては対象となる橋下の利用状況之供給 施設の添架状況を要因として評価する方法を示した。

（3）上記の方法を適用するため, 独自の地理情報シ ステムである「道路地図情報システム」を新たに開発し た。この方法, システムを東京都建設局管理の 1000 を 越える橋に適用した結果, 橋の防災上の重要度をシステ マティックに評価しうることが確認できた.

この手法は, 橋以外の道路施設, 例えばトンネル, 擁 壁, 盛土, 斜面等にも適用することが可能であり, 道路 網全体を対象にした耐震保全対策事業の実施計画策定に 反映することができる. 今後, 関連するデータベースの 整備を図るとともに，各評点や重みにより客観性を持た せるなど，より信頼度の高いシステムとして整備するこ とが必要である.

この研究を実施するにあたり貴重な御指導，御助言を 
いただいた東京大学生産技術研究所 片山恒雄教授をは じめとする関係各位に対し，深く感謝の意を表する次第 である．最後に本研究を進めるにあたり，終始協力いた だいた暒谷孝男, 吉澤光雄, 伊藤勇治郎 (東京都建設局), 野中昌明, 井出孝 (日本技術開発 (株)), 永田茂 (現鹿 島建設(株)）の各氏に心からの謝意を表する。なお，図 ー7〜9等の道路地図情報システムの作成にあたっては, 一部国土数值情報を使用したことを付記しておく.

\section{参考文献}

1）建設省都市局・道路局：所管施設の地震に対する安全性 等に関する点検, 1991 年 5 月.

2) Applied Technology Council : Seismic Retrofitting Guidelines for Highway Bridges, ATC-6-2, Palo Alto, California, Aug., 1983.

3) A. Longinow, E. Bergman and J.D. Cooper : Bridge
Retrofitting Sellection of Critical Bridges in a Road Network, The Current State of the Knowledge of Lifeline Earthquake Engineering, Proc. of the Technical Council on Lifeline Earthquake Engineering, ASCE, Aug., 1977.

4) Buckle, I.G. : Screening Procedures for the Retrofit of Bridges, Proc. of the 3 rd U.S. Conference Sponsored by the Technical Council on Lifeline Earthquake Engineering of the ASCE, Aug., 1991.

5）東京都防災会議：東京都地域防災計画震災編（平成 4 年 修正), 1992 年 10 月.

6）東京都都市計画局：あなたのまちの地域危険度，1993 年.

7）腰塚武志, 大木 豊：橋の相対的密度に関する考察, 第 17 回日本都市計画学会学術研究発表論文集, 1982 年.

8）東京都建設局内部資料：交通量調査報告書に基づいた データベース.

9）東京都建設局：道路構成調書, 1992 年 3 月.

(1994.3.24 受付)

\title{
IMPORTANCE FACTOR EVALUATION OF EXISTING ROAD BRIDGES FOR A SEISMIC DISASTER MITIGATION PLAN
}

\author{
Jiro SATO, Yukio SINOZAKI, Mitsuaki SAEKI and Ryoji ISOYAMA
}

\begin{abstract}
An importance factor evaluation procedure is presented for existing road bridges in a metropolitan area in order to establish their disaster mitigation plan against earthquakes. Priority for retrofitting bridges and for emergency response after an earthquake occurrence can be decided according to the importance factor of the bridge as a vital transportation link.

Importance or criticality in relation to a road network is evaluated in terms of the importance of the route the bridge located in the road network as well as the direct effects when the bridge is destroyed. The importance of the route is evaluated by considering daily traffic, regional land use along the route, results of network analyses including traffic demand, route assignment, trip time or distance calculations. The direct effect of the bridge failure in relasionship to utilities must be evaluated and the use of an underpass should also be considered.

This procedure has been applied to the road network and bridges in the Tokyo Metropolitan area and its usefulness has been examined.
\end{abstract}

